\title{
Article
}

\section{Loan Delinquency: Some Determining Factors}

\author{
Fennee Chong
}

check for updates

Citation: Chong, Fennee. 2021. Loan Delinquency: Some Determining Factors. Journal of Risk and Financial Management 14: 320. https:// doi.org/10.3390/jrfm14070320

Academic Editor:

Shuddhasattwa Rafiq

Received: 28 April 2021

Accepted: 6 July 2021

Published: 12 July 2021

Publisher's Note: MDPI stays neutral with regard to jurisdictional claims in published maps and institutional affiliations.

Copyright: (C) 2021 by the author. Licensee MDPI, Basel, Switzerland. This article is an open access article distributed under the terms and conditions of the Creative Commons Attribution (CC BY) license (https:/ / creativecommons.org/licenses/by/ $4.0 /)$.
Department of Accounting and Finance, Charles Darwin University, Casuarina, NT 0810, Australia; fen.chong@cdu.edu.au

\begin{abstract}
The main objective of this paper is to investigate the determining factors of loan delinquencies from the perspective of borrower attributes and loan characteristics. Empirical results indicated that the borrower-lender distance factor, collateral, education levels as well as availability of a monthly budget are having significant effects on loan delinquencies. On the other hand, level of income and gender have no significant impact on repayment behaviour. Credit is good as it allows the borrowers financial flexibility, however, debt is viewed as bad if it was not managed properly. Therefore, a correct attitude towards credit management and self-discipline can be encouraged to reduce loan default rates.
\end{abstract}

Keywords: loan delinquency; determining factors

\section{Introduction}

Prudent credit risk management to minimize loan delinquents are the challenges that financial institution faces in order to survive in both good and bad economies. High loan delinquencies could lead to a liquidity problem that causes financial institution to fall and jeopardizing the country's economy. The principles of good lending state that a loan should not be granted to a borrower until the source of repayment is reasonably certain. The occurrences of financial crisis in the United States, Dubai, Ireland and Greece have provided further evidences that easy availability of credits could led to unprecedented levels of debt. During the 2008 financial crisis, total debt in U.S. and Europe amounted to three times of the countries' GDP (Dhameja 2010). Indeed, the high repayment defaults in these countries had caused bankruptcy and closure of banks and financial institutions.

Two main financial groups are involved in providing credits to the Malaysian borrowers. They are the banking system and the non-bank financial intermediary. The banking system is made up of the commercial banks, the merchant banks and the Islamic banks whilst the non-bank financial intermediaries consist of development financial institutions and others which are established to develop and promote key sectors that are considered of strategic importance to the overall socio-economic development objectives of the country (Central Bank Malaysia 1994). Also included under this group are the insurance companies. Prior studies on loan default rates are mainly concentrated on the credit scoring model and institutional factors. Nonetheless, identifying reasons behind loan delinquencies from the borrowers' point of view is crucial as well. With this in mind, the objective of this paper is to present factors contributing to loan delinquencies from the borrowers' perspective. Since the commercial banks and the non-bank financial intermediaries are the main financial provider in the country, samples for this study are collected from these two categories. This paper is organized as follows: Section 2 presents the relevant literature. Data and methodology are described in Section 3. Section 4 presents the descriptive statistics and test results while Section 5 concludes the study.

\section{Literature Review}

Numerous authors suggested that when a loan is delinquent it may be a result of the borrowers' unwillingness or inability to repay (Quercia and Stegman 1992; Greenbaum 
et al. 2019; Godquin 2004; DeYoung et al. 2008; Kassim and Rahman 2018). This premise underlines the credit assessment procedures that traditional lenders have used in screening potential borrowers. Until today, the credit scoring model is the most prominent model used in assessing credit risk by many financial institutions. The five areas which are normally included in the credit scoring model are collateral, which refers to the asset used to secure the debt, capacity that measures borrower's ability to service repayment, character which refers to the borrower's track record, condition of the economy of the borrowers, as well as capital which refers to net worth of the borrower (Greenbaum et al. 2019). Based on the credit analysis done, lenders will not lend to the loan applicants if they perceive that the loan applicant is too risky and would default the loan. However, besides the variables commonly used in the credit scoring model, other factors should also be scrutinized.

Socioeconomic characteristics such as education attainment, gender as well as personal attitude towards credit management are among these factors. An earlier study by Martin (1997) analysed the determinants of the repayment performance of Grameen Bank borrowers discovered that education level and the area of land possessed by the borrowers have a positive impact on repayment performance. In terms of gender, Derban et al. (2005) reported that women borrowers lead to a lower loan loss rate in their study. Nevertheless, Godquin (2004) contended that female borrowers are not a better pay master than their male counterparts. This finding was supported by Bassem (2008), and Kassim and Rahman (2018) findings indicating lending to women in Tunisia and Malaysia didn't contribute meaningfully to a better repayment performance even though women are generally recognized as more responsible and better disciplined compared to men.

A similar study by Lu et al. (2009) on informal lending found that loan characteristics such as maturity, credit culture, previous debt, capacity as well as borrowers' attributes like marital status, health, age and native place are some of the underlying factors contributing to the default rate. Kim (2015) posited that households tend to default their unsecured loan to secure homeownership, indicating the relevancy of a collateral requirement in reducing delinquency or default.

Studies also reported both 'soft' and 'hard' information could affect repayment patterns of the borrowers (DeYoung et al. 2008). Soft information such as a large borrowerlender distance is associated to higher default risk as distance interferes with information collection about the borrowers. DeYoung et al. (2008) contended that geographic proximity can impact borrowers' capability and willingness to collect "soft' non-quantitative information necessary to access the borrowers' creditworthiness. It is not uncommon that lenders are reluctant to visit loan applicants who are far from their respective financial institutions. This practice could lead to information asymmetries whereby good customers were rejected while 'defaulters' were granted loans based on hardcore information provided in the applications. As a matter of fact, information asymmetry is one of the main factors affecting credit risk exposure of microenterprise financing which take place when lender is having difficulties seeking and apprehending information regarding creditworthiness of the borrowers (Godquin 2004). Kassim and Rahman (2018) stated that borrower-specific moral hazard issues such as withholding information on existing credit arrangements which resulted to overstretched commitment, and the lack of motivation to fulfil financial commitments have increase the risk of default among microfinance borrower in Bangladesh.

In fact, the need to include measures of psychological attributes such as stability, a sense of commitment and future orientation when assessing factors affecting loan delinquencies was suggested by Smith (1964). This assertion was sustained by Godquin (2004)'s study which found that loan defaults are associated with borrowers' attitude as borrowers who have enough money to reimburse had opt to delinquent their credit obligations strategically. Some creditors would look at the credit history and paying habits from information obtained through credit reporting agencies if available (Arslan and Karan 2010). Puri et al. (2017) studied loans made by German banks asserted that a practical solution to reducing loan defaults for new customers is to encourage customer to open a transaction account 
which allows banks to assemble information about spending habit of the customer and use this as a baseline for screening before making lending decision. They also found that banks with relationship-specific information act differently compared with those that do not have this information both in screening and monitoring loan repayment activities.

A later study by Aristei and Gallo (2016) on the determinants of Italian households' repayment difficulties on mortgage loans asserted that younger borrower, decreasing income level, immigrant status and institution's less effective measure at punishing defaulters are positively related to the existence of negative repayment behaviour. The authors recommended policy interventions to enhance efficiency of credit risk management among financial institutions and efforts are required to improve financial literacy so that household mortgage repayment difficulties and the likelihood of insolvencies can be reduced. Some of these findings are akin to those of Gerardi et al. (2010) which contended that there is a significant negative correlation between numerical ability and loan delinquency, and financial literacy was a determinant of subprime mortgage crisis. Indeed, the importance of good financial self-efficacy which is characterized by better financial knowledge and positive financial behaviours are associated with better financial wellbeing including debt repayment are highlighted by numerous researchers (Lown et al. 2015; Chong 2017; Shim et al. 2019). Knight and Berman (2013) and Al-Shami et al. (2020)'s findings had also reiterated the positive association between these values with timely repayment and business success.

\section{Methodology of Study}

A total of 516 questionnaires collected between 2018 to 2019 with all the required information filled by borrowers from both the local commercial banks and non-bank financial intermediaries in Malaysia were selected for analysis. The sampling technique used is a combination of simple random sampling and snow balling method. The selection of samples was determined primarily by the willingness of the participants to provide answers for the structured survey or interview on the premise that all the information gathered will be kept confidential.

As discussed before, non-bank financial institutions were set up by the government with the specific mandate to develop sectors which are important to the socioeconomic developments of the country. Due to this reason, these financial institutions are required to shoulder the risk that are not absorb by the commercial banks. Even though both types of financial institutions provide similar products and services, non-bank financial institutions are exposed to higher credit risk as their target market are higher leveraged and riskier borrowers who will be charged a higher premium on loans (Kang 2014). In order to investigate on whether there is a difference between loan delinquency rate of commercial banks and non-bank financial intermediaries, an independent sample t-test are carried out to test the following hypothesis.

Hypothesis 1. Loan delinquency rate of commercial bank borrowers is lower than that of non-bank financial institutions.

The Mann-Whitney U-test will be used to compare the distributions of scores obtained from these two independent groups. $\mathrm{H}_{0}$ is stated as there is no difference between the two groups and will be rejected when the population distributions are different. The Z-score for the Mann-Whitney test is calculated as following:

$$
\mathrm{z}=\left(U_{1}+0.5\right)-\frac{U_{1}+U_{2}}{2} / \sqrt{\frac{n_{1} n_{2}\left(n_{1}+n_{2}+1\right)}{12}}
$$

when the absolute value of the obtained $\mathrm{z}$ value is less than 1.96 , retain the $\mathrm{H}_{0}$ and vice versa.

Based on the literature review, important borrower attributes such as gender, level of education, total household income per month, availability of collateral, borrower-lender 
distance and the availability of personal financial planning will be examined on their impacts on loan repayment using a logistic regression. A logistic regression works with binomial response variables to provide prediction of a dichotomous outcome. This method is chosen for the study as the objective is to determine what causes borrower either pay or do not pay on time (binary, dichotomous) and it is suitable to be used to examine relationships between a categorical outcome variable and one or more categorical or continuous predictor variables (Peng et al. 2002; Takma et al. 2016). Logistic regression models the chance of an outcome based on individual characteristics, whereby chance is an log odds ratio and the logarithm is stated as:

$$
\log [P /(1-P)]=\beta_{0}+\beta_{1} X_{1}+\beta_{2} X_{2}+\ldots . . \beta_{m} X_{m}+\varepsilon_{i}
$$

where P indicate the probability of an event and in this study, it would be " 0 " for loan delinquency occurs or " 1 " for no delinquency.

The logistic regression model to be used for this study is expressed as following:

$$
Y_{i}=\operatorname{In}(P / 1-P)=\beta_{o}+\beta_{1} \text { GEN }+\beta_{2} E D U+\beta_{3} \mathrm{HI}+\beta_{4} \mathrm{BLD}+\beta_{5} \mathrm{COL}+\beta_{6} \mathrm{FP}+\varepsilon_{\mathrm{i}}
$$

whereby,

$\mathrm{Y}_{\mathrm{i}}=$ Delinquency ( 0 -delinquency occurs, 1 -no delinquency)

GEN = Gender (1-Male, 2-female)

EDU $=$ Level of education of the borrowers (secondary education, certificate and diploma level, bachelor's degree and postgraduate level)

$\mathrm{HI}=$ Total household income per month indicates the total gross income before taxes received by all members of a household in a month

$\mathrm{COL}=$ Collateral $(0-$ no collateral required, 1 -collateral required $)$,

$\mathrm{BLD}=$ Borrower-lender distance, refers to geographic distance between borrowers and lenders measured in Kilometres

$\mathrm{FP}=$ Available of personal financial planning such as a budget ( 0 -no monthly budget, 1 -have a monthly budget)

$\beta_{1}, \beta_{2}, \beta_{3}, \beta_{4}, \beta_{5}, \beta_{6}$ are coefficient estimates and $\varepsilon_{\mathrm{i}}$ is the error term.

The statistically significant of individual regression coefficient, $\beta$, will be tested using the Wald chi-square statistic. The explanatory variables are significant predictors for the dependent variable when $p<0.05$. The goodness-of-fit the regression model was evaluated using the Hosmer-Lemeshow statistics (Hosmer and Lemeshow 2000):

$$
C_{g}^{*}=\sum_{k=0}^{1} \sum_{k=1}^{10} \frac{\left(O_{k_{1}}-E_{k_{1}}\right)^{2}}{E_{k_{1}}}
$$

The test statistics follows a chi-squared distribution with $\mathrm{n}-2$ degrees of freedom. Based on the distribution of the $C_{g}$ for binary logistic regression, $c=2, C_{g}$ is expected to have an approximate $\chi^{2}$ distribution with $(g-2) \times(c-1)$ degrees of freedom. A nonsignificant outcome is desirable to inform that the model prediction does not significantly differ from the observed.

\section{Findings and Discussion}

\subsection{Descriptive Statistics}

From the 516 samples selected for analysis, $47 \%$ of the respondents obtained credit facilities from the commercial banks while the remaining 53\% have a loan from the nonbank financial institutions. In terms of gender, $52.8 \%$ of the respondents are male while the rest are female. Meanwhile, $65 \%$ of the respondents attained certificate or tertiary education while the remaining achieved secondary level of education. In addition, 39.6\% of the respondents have a total household gross income of RM3000-RM7000 per month. Meanwhile, distance from the loan providers is ranging from $5 \mathrm{~km}$ to $27 \mathrm{~km}$ with an average of $12 \mathrm{~km}$. On the other hand, $51 \%$ of the loans were granted without collateral. 
In terms of repayment performance, $35.47 \%$ of the respondents delinquent in their loan instalments. Further interview indicates that within this delinquent group, $19.57 \%$ of them pay their outstanding loan obligations within a month while the remaining take between two to six months to pay off their overdue instalments.

\subsection{Delinquency Rate between Commercial Bank Borrowers and Non-Bank Financial Intermediaries Borrowers}

An independent sample t-test was performed to assess on whether delinquency rate of borrowers of commercial banks are significantly different from that of the non-bank financial institutions. From the results exhibited in Table 1, loan delinquency rate of borrowers from non-bank financial institutions is $9.3 \%$ higher than that of the commercial banks. This difference was further supported by the Mann-Whitney $U$ test results which reported a Z-score of -2.126 (and significant at the $p$-value of 0.033 ). As the absolute value of Z-score is more than 1.96, we can accept $\mathrm{H} 1$ and conclude that loan delinquency rate between the two groups of financial intermediaries is different.

Table 1. Independent Sample Mann-Whitney U Test Results.

\begin{tabular}{|c|c|}
\hline Loan delinquency rate of Commercial Bank Respondents (\%). & 30.5 \\
\hline Loan delinquency rate of Non-Bank Financial Intermediaries (\%) & 39.8 \\
\hline Z-score & -2.126 \\
\hline$p$-value & $0.033^{* *}$ \\
\hline
\end{tabular}

\subsection{Analysis on Factors Contributing to Loan Delinquencies}

As discussed above, logistic regression method was used to analyse the model proposed to predict the probability of delinquency in loan repayment. The dependent variable used in the logistic model is the probability of loan delinquency. It is a dummy whereby those who did not pay on time are classified as Delinquency $=0$ whilst respondents who pay on time are represented by No delinquency $=1$. Based on the literature review, the predictor variables selected are gender, level of education, total household income per month, availability of a collateral, distance from the loan providers (in kilometres) as well as availability of financial planning such as a monthly budget.

Table 2 presents the logistic regression results. From the results, Omnibus Test of Model Coefficients give a Chi-Square of 92.171 on $6 \mathrm{df}$, and significant at $p=0.001$ while Hosmer and Lemeshow Goodness-of-Fit test statistics has a $p=0.496$. Both results imply that the model's estimates fit the data used at an acceptable level and it is also able to explain the variance of the dependent variable to a significant degree (Hosmer and Lemeshow 2000). In addition, findings from the logistic regression coefficient with a 0.05 criterion of statistical significance indicated that education attainment, borrower lender distance, availability of collateral as well as financial planning such as preparation of monthly budget has significant effects on the loan delinquency rates. A higher education attainment is significantly contributed to a lower delinquency rate. On the other hand, a larger borrowerlender distance is significantly associated with poorer repayment performance, whereby each one unit increase of distance increases the odds of a respondent not paying his or her loan on time by 0.976 . This result supports DeYoung et al. (2008)'s finding. 
Table 2. Logistic Regression Results.

\begin{tabular}{ccccc}
\hline Predictor & $\boldsymbol{\beta}$ & Wald $\boldsymbol{\chi}^{\mathbf{2}}$ & $\boldsymbol{P}$ & Odds Ratio \\
\hline Gender & 0.340 & 2.706 & 0.100 & 1.405 \\
EDU (Education attainment) & -0.289 & 7.016 & 0.008 & 1.335 \\
HI (Household income) & 0.105 & 1.643 & 0.200 & 1.110 \\
COL (Collateral) & 0.801 & 14.565 & 0.001 & 2.228 \\
BLD (Borrower-lender distance) & -0.025 & 10.687 & 0.001 & 0.976 \\
FP (Financial planning) & 0.552 & 23.268 & 0.001 & 1.737 \\
\hline Test & & $\chi^{2}$ & & \\
\hline Model Summary & & & \\
\hline Overall model evaluation & & & \\
Omnibus Tests & & & \\
Goodness-of-fit test & & & \\
Hosmer \& Lemeshow & & & \\
\end{tabular}

Note: The cut-off value is 0.05 .

Moreover, delinquency rate showed significant decreases if collateral is provided to obtain the credit facility. The likelihood of the borrowers providing collateral paying on time is 2.228 times more than that of those not providing collateral when the loan is granted. Finally, having the right attitude and discipline in managing credit risk by practising financial planning such as preparing a budget also reported to enhance creditworthiness. As show in the finding, the availability of a monthly budget increases the odds of paying on time by 1.737 times. This finding is in line with those of Godquin (2004), Gerardi et al. (2010) and Kassim and Rahman (2018).

Nevertheless, total household income per month (proxy of capability) was found not having significant predictive power over delinquency rates. This result supported Godquin (2004) and Shim et al. (2019) which contended that even though with enough financial capacity, borrowers would opt to delinquent their loan repayments. Contradictory to Derban et al. (2005), gender was found as not having any determining effect over loan delinquencies. Nonetheless, this finding was in-line with that of Bassem (2008) and Al-Shami et al. (2020).

\section{Conclusions}

Based on the findings from the analysis of 516 loan customers, this study found that financial institutions in Malaysia need to practise more prudent credit risk management. Findings showed that approximately $35 \%$ of the respondents did not pay their loan obligations on time. Furthermore, non-bank financial institutions were found to be subjected to a significantly higher loan delinquency rate.

Findings also indicate that the most effective measure to reduce loan delinquency is to enforce a collateral requirement. By imposing collateral as one of the compulsory criteria in loan application, borrowers become more mindful about the consequences from loan delinquency as the lender can seize the collateral and put up for sale to recoup some of its losses from default. To mitigate the adverse effect of borrower-lender distance on loan repayment performance, lenders can carry out more visitations, encourage customer to open a transaction account before granting credit facility (Puri et al. 2017) and using referees for new customers are recommended good practices before approving a loan. Other factors such as education attainment should be assigned some weightage as it has a significant inverse relationship with loan delinquency rates. Since practicing financial planning such as preparing a monthly budget enhances time repayment behaviour, promoting financial literacy could be made as one of the corporate social responsibilities among financial institutions to educate and to prevent loan delinquencies or default.

Funding: This research received no external funding.

Institutional Review Board Statement: Not applicable. 
Informed Consent Statement: Not applicable.

Data Availability Statement: Not applicable.

Conflicts of Interest: The authors declare no conflict of interest.

\section{References}

Al-Shami, Sayed, Mamun Abdullah, Sidek Sarifah, and Rashid Nurulizwa. 2020. Causes of failure among Malaysian female entrepreneurs-A qualitative case study of Malaysian microcredit borrowers. Qualitative Research in Finance 12: 43-71.

Aristei, David, and Manurla Gallo. 2016. The determinants of households' repayment difficulties on mortgage loans: Evidence from Italian microdata. International Journal of Consumer Studies 40: 453-65. [CrossRef]

Arslan, Ozgur, and M. Baha Karan. 2010. Consumer credit risk characteristics: Understanding income and expense differentials. Emerging Markets Finance \& Trade 46: 20-37.

Bassem, B. Soltane. 2008. Determinants of successful group loan repayment: An application to Tunisia. Journal of Sustainable Development in Africa 10: 766-800.

Central Bank Malaysia. 1994. Money and Banking in Malaysia: 35th Anniversary Edition. Kuala Lumpur: Bank Negara Malaysia.

Chong, Fennee. 2017. Factors affecting credit card debt payment in Malaysia. International Journal of Business E Economics 16: 21-30.

Derban, K. William, Binner M. Jane, and A. Mullineux. 2005. Loan repayment performance in community development financial institutions in the UK. Small Business Economics 25: 319-32. [CrossRef]

DeYoung, Robert, Glennon Dennis, and Nigro Peter. 2008. Borrower-lender distance, credit scoring, and loan performance: Evidence from informational-opaque small business borrowers. Journal of Financial Intermediation 17: 113-43. [CrossRef]

Dhameja, Nand. 2010. Global Financial Crisis: Impact, challenges \& Way-out. The Indian Journal of Industrial Relations 45: 336-48.

Gerardi, Kristopher, Goette Lorenz, and Meier Stephan. 2010. Financial Literacy and Subprime Mortgage Delinquency: Evidence from a Survey Matched to Administrative Aata. Working Paper 2010-2010: Federal Reserve Bank of Alanta. Available online: http:/ / www.frbatlanta.org (accessed on 21 December 2020).

Godquin, Marie. 2004. Microfinance repayment performance in Bangladesh: How to improve the allocation of loans by MFIs. World Development 32: 1909-26. [CrossRef]

Greenbaum, Stuart, Thakor Anjan, and Boot Arnoud. 2019. Contemporary Financial Intermediation, 4th ed. Academic Press. Available online: https: / / www.elsevier.com/books/contemporary-financial-intermediation/greenbaum/978-0-12-405208-6 (accessed on 11 July 2021).

Hosmer, David, and Stanley Lemeshow. 2000. Applied Logistic Regression, 2nd ed. New York: John Wiley \& Sons, Inc.

Kang, Di. 2014. Two Essays on Nonbank Financial Institutions. Theses and Dissertations_Finance and Quantitative Methods 3. Available online: https:/ / uknowledge.uky.edu/finance_etds/ (accessed on 18 September 2020).

Kassim, H. J. Salina, and Mahfuzur Rahman. 2018. Handling default risks in microfinance: The case of Bangladesh. Qualitative Research in Finance 10: 363-80. [CrossRef]

Kim, Jiseob. 2015. Household's optimal mortgage and unsecured loan default decision. Journal of Macroeconomics 45: 222-44. [CrossRef]

Knight, and Karen Berman. 2013. Financial intelligence for entrepreneurs: What you really need to know about the numbers. In Choice Reviews Online. Boston: Harvard Business Review Press.

Lown, Jean M., Jinhee Kim, Michael S. Gutter, and Anne-Therese Hunt. 2015. Self-efficacy and savings among middle to low income households. Journal of Family and Economic Issues 36: 491-502. [CrossRef]

Lu, Wei, Xiaobo Yu, Juan Du, and Feng Ji. 2009. An empirical analysis of the default rate of informal lending-Evidence from Yiwu, China. In International Conference on Multiple Criteria Decision Making. Berlin/Heidelberg: Springer, pp. 438-46.

Martin, Imran. 1997. Repayment performance of Grameen Bank borrowers: The unzipped state. Savings and Development 21: 451-73.

Peng, C. Joanne, Lee K. Lida, and Ingersoll M. Gary. 2002. An introductin to logistic regression analysis and reporting. The Journal of Educatonal Research 96: 3-14. [CrossRef]

Puri, Manju, Rocholl Jorg, and Steffen Sascha. 2017. What do a million observations have to say about loan defaults? Opening the black box of relationships. Journal of Financial Intermediation 31: 1-15. [CrossRef]

Quercia, G. Roberto, and Michael, A. Stegman. 1992. Residential mortgage default: A review of the literature. Journal of Housing Research 3: 241-379.

Shim, Soyeon, Serido Joyce, and Sun-kyung Lee. 2019. Problem-solving orientations, financial self-efficacy and student-loan repayment stress. The Journal of Consumer Affairs, 1273-96. [CrossRef]

Smith, Paul. 1964. Managing risk on consumer instalment credit. Management Science 11: 327-40. [CrossRef]

Takma, Cigdem, Guneri I. Oznur, and Yakut Gevrekci. 2016. Investigation of stillbirth rate using logistic regression Analysis in Holstein Friesians Calves. Journal of Agriculture Faculty of Ege University 53: 245-50. 